\title{
SELECTED TEMPERATURE CHARACTERISTICS OF BRNO AND SURROUNDING AREA
}

\author{
Karel Dejmal, Petr Koláŕ, Josef Novotný, Alena Roubalová
}

\begin{abstract}
The paper sets out to evaluate air temperature in Brno and its surrounding area. Data from professional station Brno-Turany as well as institutional and amateur stations dated 2015 and 2016 were used as a basis. The evaluation draws data from joint dates recorded on those stations. Result presents a summary of basic elements influencing air temperature in Brno and its surroundings. The impact of sensor placement and microclimatic conditions on measured air temperature values is more significant than the impact of altitude and latitude. The most significant factors for air temperature appeared to be the positioning in valley-like locations, type of surface around the station and shadowing of sensors by objects in proximity of stations. Despite the cited influences the data from majority of amateur meteorological stations could be considered as serviceable for air temperature monitoring.
\end{abstract}

Keywords: air temperature, amateur meteorological stations, Brno, monitoring

\section{Introduction}

At present the temperature conditions in the Czech Republic are evaluated on the base of data from meteorological stations run by the Czech Hydrometeorological Institute (CHMI). Although the number of synoptic and mostly automated climatological stations exceeds 200 , the complete coverage of our territory and consequently a correct interpretation of air temperature data in some areas with specific microclimatic conditions is not successful. The aim of our paper is to provide an evaluation of temperature conditions in Brno and surrounding areas within a $25 \mathrm{~km}$ range through data obtained from professional, institutional and amateur meteorological stations. Besides the CHMI, the amateur data could be collected from the Amateur Meteorological Society (AMS) and from owners of private meteorological stations nowadays. Contrary to those of the CHMI, most of amateur stations do not comply with standards of the World meteorological organization (WMO), thus do not always present an ideal basis for climatological purposes (CHMI, 2011, WMO, 2008). Apart from elementary physical-geographical factors other parameters such as placement of temperature sensors, type of surface and a complexity of station surroundings play a certain role. All those parameters influence the air temperature in specific locations and in 
the case of some amateur stations they are a principal cause of problematic quality of their data (Dejmal et al., 2018).

Quality data from amateur meteorological stations could however become a good source of information about actual weather, and might even be usable for climatological analyses. Eventually such data could contribute to the development of meteorological applications designed for special purposes (e.g. transportation, tourism, agriculture) just as they do in the United States (Bristow et al., 2005).

\section{Data and methods}

The original group of 19 stations providing data for evaluation of air temperature in Brno and surrounding area for years 2015--2016 was reduced to 13. 6 stations were completely excluded and classified as unusable for further purposes on the base of a preceding analyses and study due to low quality data outcomes (Dejmal et al., 2018). The professional station Brno-Tuřany, operated by CHMI, was appointed a reference station for comparison of temperature data from different locations. The station is situated on the outskirts to the south-east from the city. Though it meets all parameters specified by WMO standard, it is nevertheless located close to the urban centre and air traffic area, which are factors that increase the air temperature at the station. The rest of the stations are either operated by private individuals (amateur stations) or institutions of university or other type. All the stations are within $25-\mathrm{km}$ range from the reference station. Their spatial distribution is illustrated in Figure 1 and a more detailed information about specific stations is given in Table 1.

Figure 1: Spatial localization of employed meteorological stations in Brno and surrounding area; abbreviations of station names are explained in Tab. 1 (CP - the Černá Pole locality, containing two stations - Met, Arb)

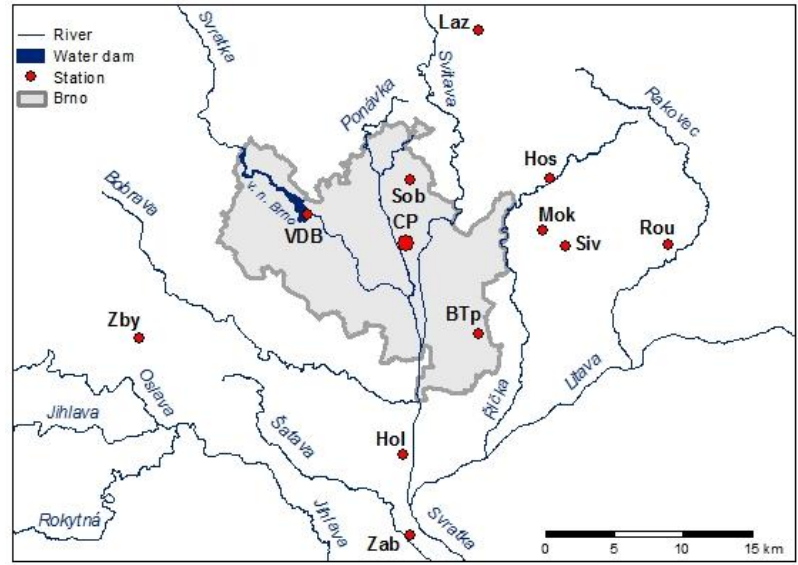


Table 1: The list of stations and their characteristics (station type: A - amateur, I - institutional, P - professional)

\begin{tabular}{|l|r|r|r|r|}
\hline \multicolumn{1}{|c|}{ Station name } & Abbr. & $\begin{array}{c}\text { Station } \\
\text { type }\end{array}$ & \multicolumn{1}{c|}{$\begin{array}{c}\text { Altitude } \\
{[\mathbf{m}]}\end{array}$} & $\begin{array}{c}\text { Measurement interval } \\
\text { [min] }\end{array}$ \\
\hline $\begin{array}{l}\text { ČHMÚ Brno- } \\
\text { Tuřany }\end{array}$ & BTp & $\mathrm{P}$ & 241 & 30 \\
\hline ČP Arboretum & Arb & $\mathrm{I}$ & 247 & 15 \\
\hline ČP METEOS6 & Met & $\mathrm{I}$ & 248 & 10 \\
\hline Holasice & Hol & $\mathrm{A}$ & 199 & 5 \\
\hline Hostěnice & Hos & $\mathrm{A}$ & 351 & 1 \\
\hline Lažánky & Laz & $\mathrm{A}$ & 339 & 60 \\
\hline Mokrá & Mok & $\mathrm{A}$ & 325 & 10 \\
\hline Rousínov & Rou & $\mathrm{A}$ & 244 & 1 \\
\hline Sivice & Siv & $\mathrm{A}$ & 300 & 5 \\
\hline Soběšice & Sob & $\mathrm{A}$ & 383 & 60 \\
\hline VD Brněnská & VDB & $\mathrm{I}$ & 236 & 1 \\
\hline Zbýšov & Zby & $\mathrm{A}$ & 345 & 10 \\
\hline Žabčice & Zab & $\mathrm{I}$ & 180 & \\
\hline
\end{tabular}

At the beginning of data processing a verification of their completeness and correctness took place. Problem posed incorrectly measured values and data losses that are always better eliminated. Consequently, several parameters and methods were proposed in order to cancel the incorrect values and supplement data losses through interpolation. Those methods are described in-depth by Dejmal et al. (2008). Because the time period of the survey is too short (2 years), only such data were applied, whose incorrect values were removed. The definition of defective data in case of extreme air temperature minima or maxima was realized via comparison of this data with climatic atlas (Tolasz, 2017) and on the base of chronologically closest date with reference to the date of problematic measurement (e. g. one temperature value $-36,8^{\circ} \mathrm{C}$ obtained in May on the station VDB). Incorrectly measured values were intentionally reclassified as missing values and subsequently removed from analyses. Another important task was the identification of data losses that showed differently in records of different stations. (e. g. nan, -999 , and so on). Missing values were later on linearly interpolated from border values, assuming that maximum uninterrupted daily value loss was 1 hour and maximum total daily value loss did not exceed 2 hours. The arrangement considered instantaneous data every hour on the hour with exception of station Laz that regularly recorded air temperature values in 53rd minute. Seeking to process maximum possible number of stations this 7-minute time difference in record was neglected and all obtained values from Laz station were always assigned to the coming hour. In order to be able to intercompare the data, the measuring days 
containing data loss (loss days) were also removed from further analyses. Striving to obtain as many joint days as possible (at least $65 \%$ per month), the problematic stations in some months were eliminated as well. Details are summarized in Table 2. All considered measuring days were recorded in Central European Time (CET).

Table 2: The number of joint days without failure during individual months in 2015-2016

\begin{tabular}{|c|c|c|c|c|}
\hline Month & $\begin{array}{c}\text { Max. number of } \\
\text { days }\end{array}$ & Joint days & Joint days [\%] & $\begin{array}{c}\text { Removed } \\
\text { stations }\end{array}$ \\
\hline January & 62 & 44 & 71 & $\mathrm{Hol}$ \\
\hline February & 57 & 48 & 84 & Hol, Mok \\
\hline March & 62 & 50 & 81 & Mok, Siv \\
\hline April & 60 & 52 & 87 & Laz, Mok \\
\hline May & 62 & 48 & 77 & \\
\hline June & 60 & 41 & 68 & Mok \\
\hline July & 62 & 53 & 85 & Laz, Mok \\
\hline August & 62 & 40 & 65 & \\
\hline September & 60 & 45 & 75 & \\
\hline October & 62 & 42 & 68 & Siv \\
\hline November & 60 & 43 & 72 & $\mathrm{Laz}$ \\
\hline December & 62 & 49 & 79 & Laz \\
\hline
\end{tabular}

Every considered station has certain characteristics. Those can show in the obtained data and influence the overall interpretation of temperature conditions at the given station. Due to this fact it was necessary to carry out a field research of our stations and collect station metadata from their operators. The parameters affecting measurements were determined according to valid meteorological standards (WMO, 2008) and with regard to Dejmal et al. (2018). Observed parameters for individual stations are shown in Table 3.

The analysis of temperature conditions was developed on the base of calculation of temperature differences between individual stations and station BTp. The temperature differences $\left({ }^{\circ} \mathrm{C}\right)$ are demonstrated in charts, that present daily course of air temperature throughout the year, where hourly data are average values from years 2015-2016. First, there are urban-type stations situated in Brno (Arb, Met, Sob, VDB), followed by stations to the east of Brno (Mok, Siv, Hos, Rou) and then the rest (Hol, Zab, Laz, Zby). The order within each group is given by the distance from reference station (smallest to largest). The stations with no charts are stations with problematic data presented in Table 2. Since those stations are lacking a significant part of data (15\% data loss in a given month), the applied method of graphic representation is not appropriate. 
Table 3: Summary of parameters influencing air temperature data according to WMO (2008) and Dejmal et al. (2018); terrain (F - flat, R - ridge, S - slope, V valley), surface ( $\mathrm{G}$ - grass, $\mathrm{M}$ - mixed, $\mathrm{P}$ - paved)

\begin{tabular}{|l|l|l|l|l|l|l|}
\hline Station & Obstacles & Terrain & Surroundings & Placement & Surface & $\begin{array}{c}\text { Exposition } \\
{\left[{ }^{\circ}\right]}\end{array}$ \\
\hline BTp & NO & F & rural & space & M & $0-360$ \\
\hline Arb & YES & F & city & space & G & $0-360$ \\
\hline Met & YES & F & city & space & M & $330-30$ \\
\hline Hol & YES & F & rural & space & M & $360-180$ \\
\hline Hos & YES & V & forest & space & G & $260-80$ \\
\hline Laz & YES & V & rural & space & G & $240-10$ \\
\hline Mok & YES & V & rural & space & G & $45-190$ \\
\hline Rou & YES & S & rural & space & M & $235-145$ \\
\hline Siv & YES & V & rural & space & G & $45-240$ \\
\hline Sob & YES & R & rural & wall & P & $210-240$ \\
\hline VDB & YES & S & rural & space & G & $0-180$ \\
\hline Zby & YES & F & rural & wall & M & $360-90$ \\
\hline Zab & NO & F & rural & space & G & $0-360$ \\
\hline
\end{tabular}

\section{Results}

Figure $2 \mathrm{a}, 2 \mathrm{~b}$ illustrates average hourly air temperatures per month for the period 2015-2016 at the station BTp. The most distinct daily course occurred in the summer months (June-August), where the amplitude amounted to $9,6-10,4{ }^{\circ} \mathrm{C}$. On the other hand the least distinct course took place in winter (DecemberFebruary), where amplitude of air temperature was between $1{ }^{\circ} \mathrm{C}$ and $4{ }^{\circ} \mathrm{C}$. The amplitude in spring (March-May) scored $6,7-9,2{ }^{\circ} \mathrm{C}$ and in autumn (SeptemberNovember) $4,4-9,1^{\circ} \mathrm{C}$.

Of all stations, the Met station in the Černá Pole city quarter showed the smallest temperature differences (within interval $\langle-1 ; 1\rangle$ ), and so the air temperature recorded on this station did not vary much from that of reference station BTp. As illustrated in Figure 3, the largest negative differences were attained in the morning in summer period, which was caused by shadowing resulting from obstacles (trees) in the proximity. The boldest positive differences were showed in the evening from May to July. Those months are characteristic by the highest number of hours of daylight and longest days. Even though the station was shadowed again from $6 \mathrm{pm}$, the positive differences on some evenings were boosted due to the proximity of reinforced surface that retained higher temperature 
in the city than on a grassy surface after sunset (Dobrovolný, 2013). The average temperature at Met station was merely $0,03{ }^{\circ} \mathrm{C}$ higher than at the station BTp.

Figure 2: Daily air temperature at the station BTp in the months January-June (a) and July-December (b) in 2015-2016

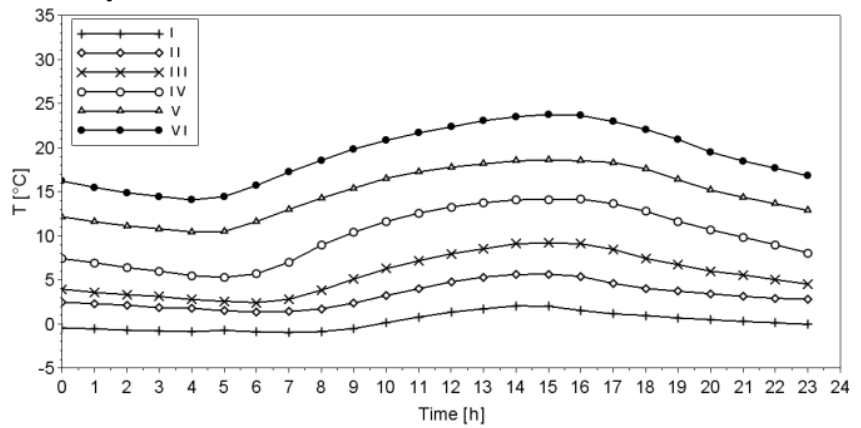

(a)

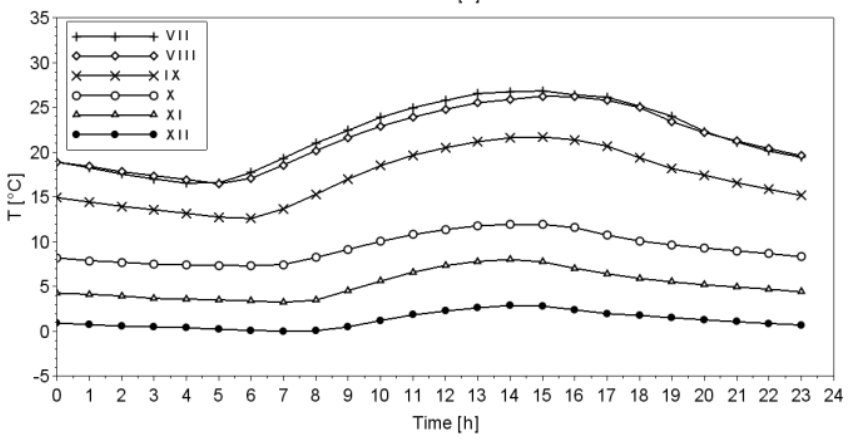

(b)

Figure 3: Air temperature difference at the station Met in 2015-2016

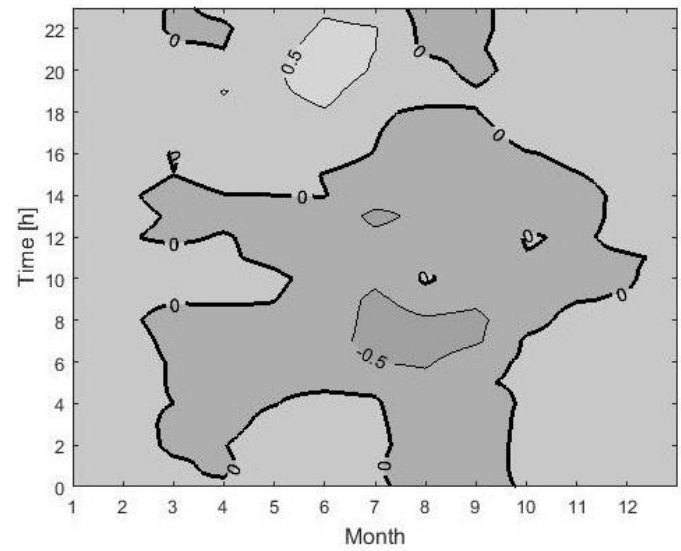


The Arb station (Figure 4) lies also in the Černá Pole quarter, but in contrast with Met it is positioned on a grassy surface and its surroundings are much more favourable for meteorological measurements. Its differences ranged $\langle-2,2 ; 0\rangle$ and on average the air temperature here was $0,7{ }^{\circ} \mathrm{C}$ lower than at BTp. As demonstrated in Figure 4, the air temperatures differed from BTp records mostly in spring and summer and then in the morning, when the station was shadowed by trees. The temperature sensor got out of shadow around noon and till this moment the recorded temperatures were $0,1-0,5^{\circ} \mathrm{C}$ lower than at BTp. At nighttime cooling was more remarkable mainly with radiation type of weather conditions (warmer half of year). Example dates of 10. 7. $2015\left(\max \Delta \mathrm{T}=2,8^{\circ} \mathrm{C}\right.$ at $\left.4: 00\right)$ or 8. 8. $2015\left(\max \Delta \mathrm{T}=5,4{ }^{\circ} \mathrm{C}\right.$ at 5:00) showed a windless and almost cloudless situations at the station Arb. At BTp station wind speed always registered at 2-3 $\mathrm{m} . \mathrm{s}^{-1}$, the fact easily explained by open space around the station. Advection type of weather, typical for colder parts of the year, brought a less significant cooling at night. In the case of Arb the existence of urban heat island cannot be ascertained. However, it is necessary to take into account its placement inside Arboretum of Mendel university with surface area of 11 ha and the placement of reference station at the airport. That counts with unshaded open space and close proximity of runways and aircraft lines, which lead to heating of nearby reinforced surfaces in the summer.

Figure 4: Air temperature difference at the station Arb in 2015-2016

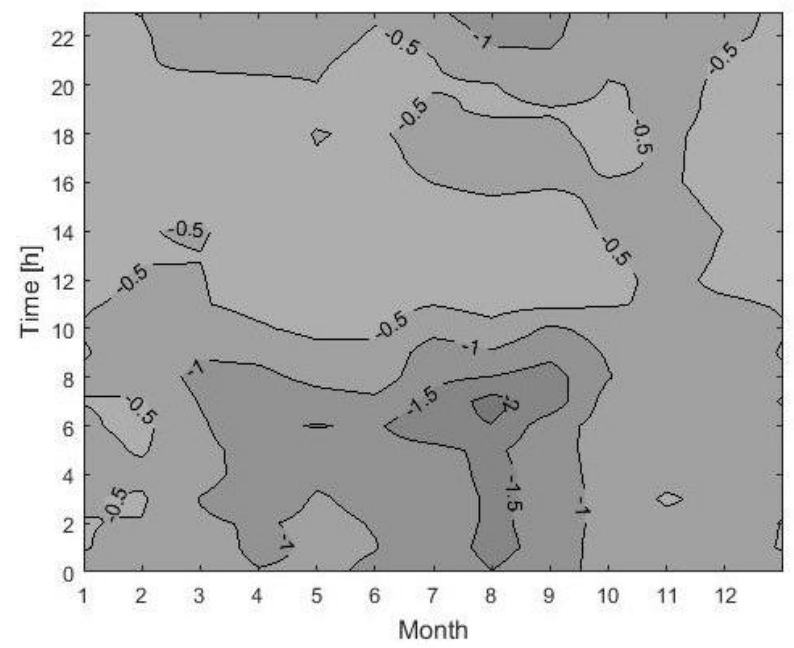

The amateur station Sob to the northwest from BTp is positioned on a cobbled courtyard behind a private property. The courtyard is oriented to the southwest, which suggest that temperatures in the late afternoon might be higher 
than at BTp. The sensor though is located on the wall close to the house and it is shadowed for most of the day. Figure 5 shows when the sun shined on the sensor. The temperature differences were however not too big and oscillated in the interval $<-1,5 ; 1>$. In comparison with BTp this station demonstrated average temperatures lower by $0,4{ }^{\circ} \mathrm{C}$, which could be explained by its altitude above sea level $(141 \mathrm{~m}$ difference between mentioned stations). Had the sensor been placed farther from the house (in the adjacent garden for example), the temperature difference would probably be higher. The current placement of the sensor however impels to count with a certain contribution of anthropogenic heat, as evidenced mainly in winter months.

Figure 5: Air temperature difference at the station Sob in 2015-2016

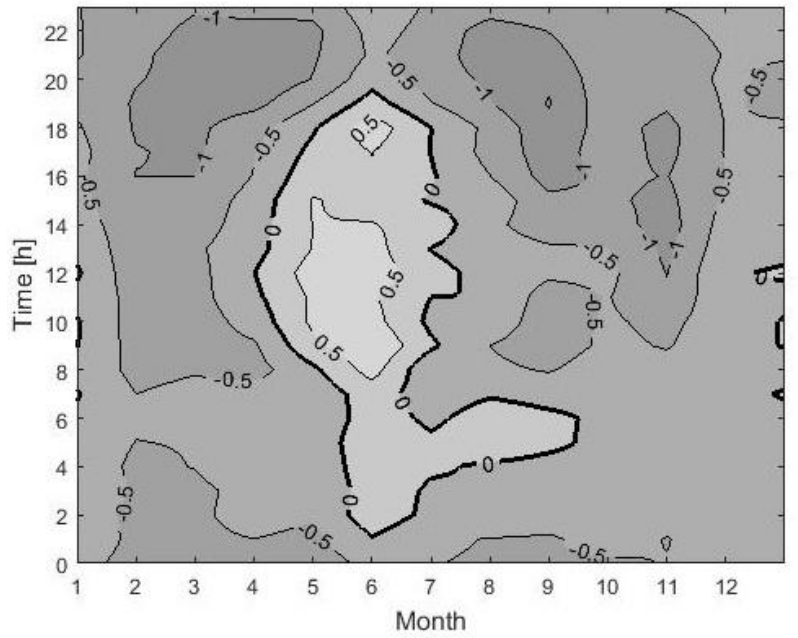

The station VDB, similarly to the above mentioned urban stations did not demonstrate a wide range of differences (Figure 6), in this case of the interval <0,$8 ; 1,7>$. In the warm half of the years the prominent role was played by the sensor placement (shadowed in the morning and exposed to the sun in the afternoon and evening). Even though the station is located on the outskirts $15 \mathrm{~km}$ to the northwest from BTp, the recorded temperatures especially in autumn were higher than at the reference station. This was caused by a close proximity of VDB to the dam Brněnská. The extensive water surface is characteristic by a substantial heat capacity that induces higher temperatures in its neighbourhood, particularly in autumn and early winter. The average temperature was $0,3{ }^{\circ} \mathrm{C}$ higher than at the station BTp.

Stations Mok and Siv registered problematic data. Both are located about $9 \mathrm{~km}$ to the northeast from BTp. The range of differences was larger compared to 
the urban stations, but it oscillated around zero all the time. The daily course of temperatures on both stations was similar to that of other stations located eastwards (Rou, Hos), but during the day positive differences prevailed, unlike at the rest of eastern stations. As all researched parameters could not be obtained from station operators, the causes of air temperature differences were not evaluated. The average air temperature calculated from available data was at most $0,3{ }^{\circ} \mathrm{C}$ lower than at the reference station.

Figure 6: Air temperature difference at the station VDB in 2015-2016

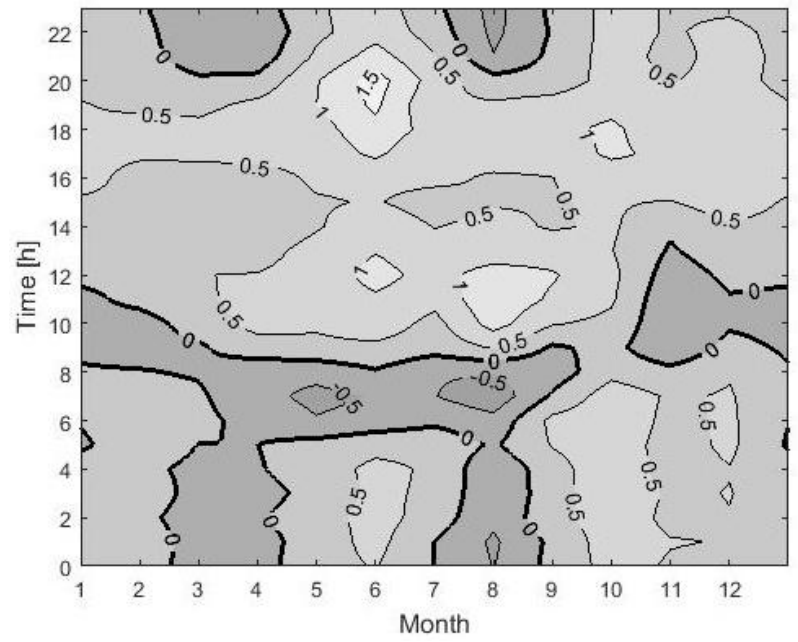

Figure 7 shows daily course of air temperature at the station Rou located $15 \mathrm{~km}$ to the northeast from BTp. It is evident, that the daily course of air temperature in contrast with urban stations was more distinct. The differences range in the interval $\langle-2,6 ; 0,4\rangle$, most notably at night in warmer parts of the years, which is due to station's location in a garden behind a building, surrounded by vegetation and on the outskirts of a small town. An increase of differences at Rou compared to BTp, as demonstrated in Figure 7, occured mainly on summer nights during radiative conditions. This was caused by a proximity of extensive reinforced surfaces of the airport close to BTp that cumulated heat during the day, and radiated it to the area in the first part of the night. The average air temperature at Rou station was $0,8^{\circ} \mathrm{C}$ lower than at the reference station.

The station Hos exposed to the north lies about $12 \mathrm{~km}$ to the northeast from the reference station, close to the village Hostěnice. Its differences from BTp (Figure 8) fluctuated in the interval $\langle-6 ;-0,3\rangle$, meaning Hos was substantially colder, mainly due to its geographic position. The station is situated in a "frost hollow", on grass surface far from urban development. It is a cause of sustainedly 
lower temperatures at nights in warmer parts of year, especially during radiationtype weather, when the cold air flows due to orography into the valley and cumulates. Another factors are its northern exposition and altitude that is $110 \mathrm{~m}$ higher than at BTp and contributed to lower recorded temperatures especially in the daytime. The average air temperature was $2,6^{\circ} \mathrm{C}$ higher than at BTp. Assuming that the temperature decreases generally by $0,65^{\circ} \mathrm{C}$ every 100 vertical meters (Répal 2012), it is possible to assert, that the impact of topography in this case was a crucial element causing low temperatures, and the altitude of the station affected lower temperatures less significantly. A certain influence on temperature can also be attributed to the surroundings of our station, covered with vegetation (grass, bushes and trees).

Figure 7: Air temperature difference at the station Rou in 2015-2016

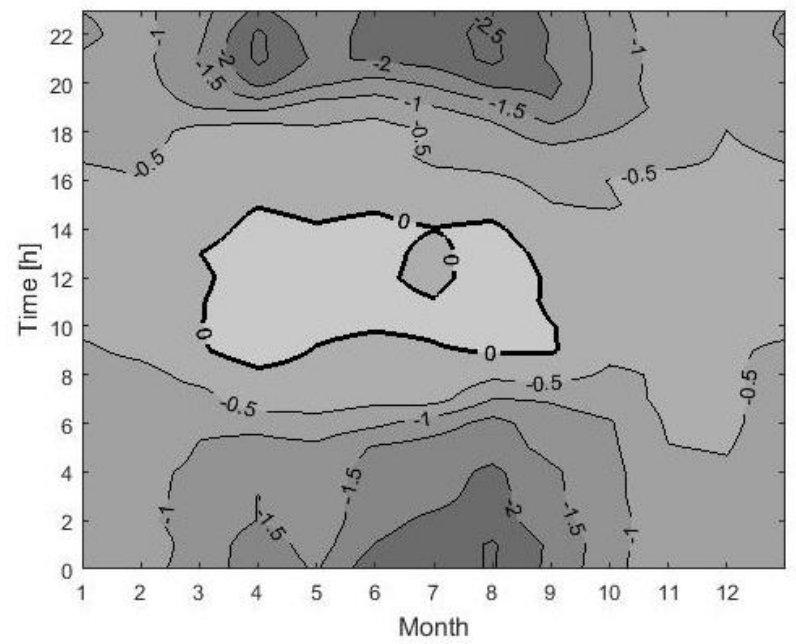

The daily course of air temperature at the station Hol located in a garden of a private property resembles that of station Arb. With difference range $<-2,3 ; 1,9>$ the daily temperature amplitude was though somewhat bolder. Similarly to Mok and Siv stations, the differences from BTp reached both positive and negative values, the former peaking in the afternoon in warmer periods. In general, the average temperatures was $0,2{ }^{\circ} \mathrm{C}$ higher, which could be caused by southern location and lower altitude. Due to inaccessibility of the station's site it is not feasible to state other parameters with certainty (such as distance from artificial surfaces) possibly influencing measurement process.

The station $\mathrm{Zab}$ is the southernmost station planted $15 \mathrm{~km}$ from BTp. Figure 9 illustrates a bolder daily course than at the reference station, which is due to its location in open land away enough from urban development and with only 
agricultural anthropogenic activity. Besides BTp it is the only station that complies with meteorological standards of WMO and its measurement should not be influenced by external parameters. In case of ideal location of researched stations their daily course of air temperature differences should resemble temperature distribution at this station. In this case only physical-geographical factors influenced the air temperature; especially latitude and altitude of the station, which is situated $61 \mathrm{~m}$ lower than BTp. The differences from BTp oscillated between <2,$2 ; 1,7>$ and the average temperature was merely $0,04{ }^{\circ} \mathrm{C}$ higher.

Figure 8: Air temperature difference at the station Hos in 2015-2016

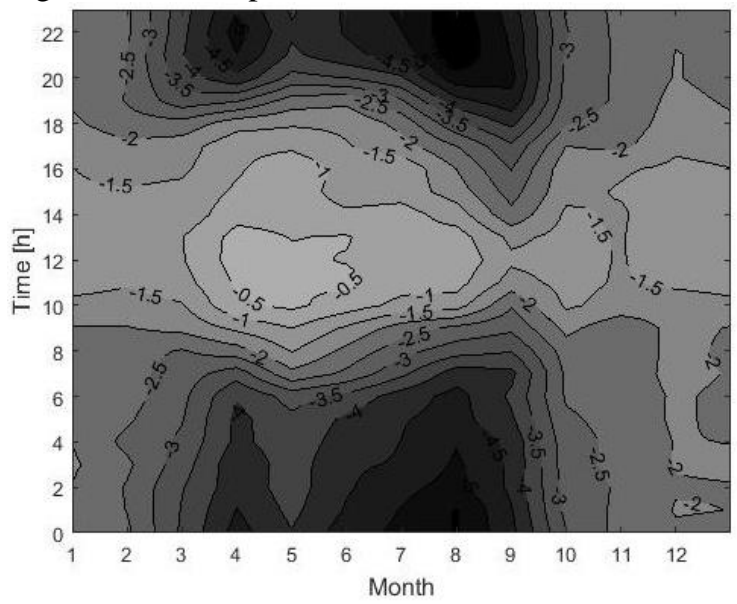

Figure 9: Air temperature difference at the station Zab in 2015-2016

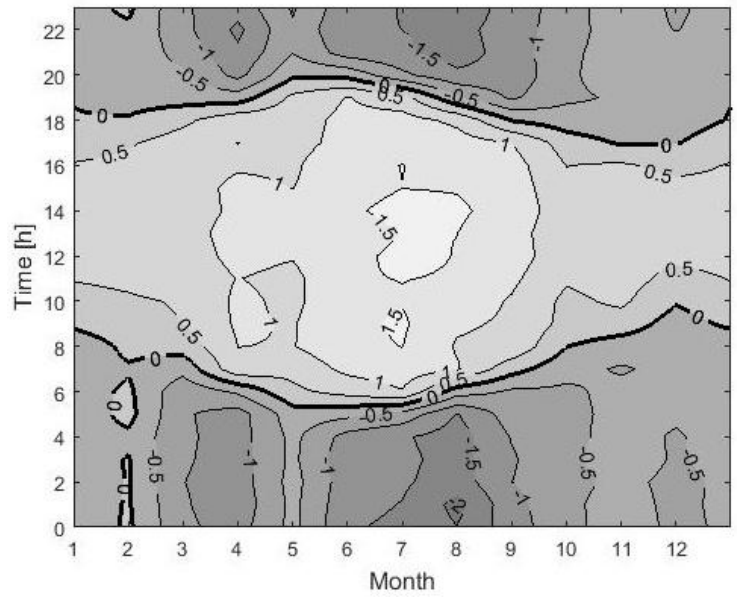


The northernmost station Laz returned largest negative differences in comparison with other stations. An absolute maximum difference occurred in August in the morning, when the recorded temperature difference from BTp amounted to $-6,4^{\circ} \mathrm{C}$. Besides western exposition, positioning among vegetation and atypical sort of radiation cover (wooden booth), a significant role could be assigned to the valley-like placement that induces accumulation of cold air in the area. In the afternoon, when the sensor is exposed to direct sunlight, temperature rose rapidly. The average temperature difference was $-1,6^{\circ} \mathrm{C}$.

The farthest station from BTp, the station Zby, lies $25 \mathrm{~km}$ to the west (Figure 10). It only showed negative differences on the interval $\langle-1,3 ;-0,1\rangle$. Even though its altitude is $143 \mathrm{~m}$ higher than at BTp, the temperature differences were relatively small. The temperature sensor is located on the wall of a building and the space is moreover closed from three sides by other buildings. That fact probably lead to compensation of all evaluated factors. The eastern exposition offers adequate conditions for overheating of the space particularly around noon in spring and summer months, and the higher temperature remained here till late afternoon. Negative differences appeared due to sensor shading from the end of summer to the early winter in the afternoon and evening. Shortening of days and decrease of daylight were also apparent. Smaller differences in wintertime were caused by emission of anthropogenic heat from neighbouring buildings. The average temperature was $0,7^{\circ} \mathrm{C}$ lower than at BTp.

Figure 10: Air temperature difference at the station Zby in 2015-2016

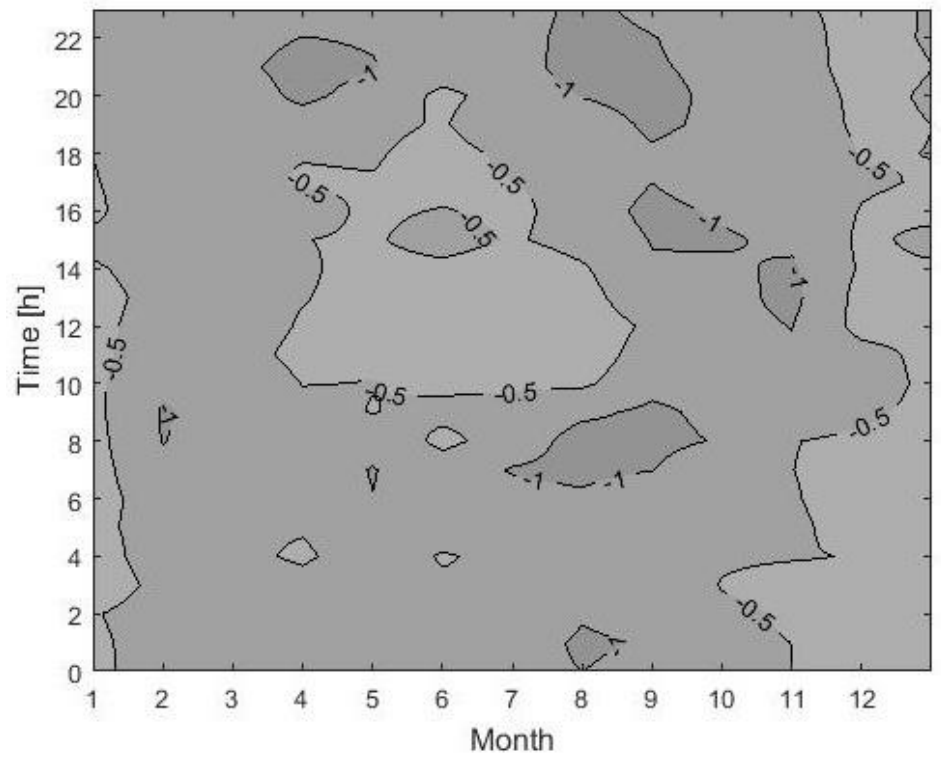




\section{Discussion and conclusion}

The above presented results imply, that despite maximum possible standardization of measuring conditions and measuring techniques, the temperature conditions of every station remain unique. Factors that most notably impact on recorded values in urban areas are (1) increased heat capacity of buildings and artificial surfaces, (2) quick drainage of water from reinforced surfaces without absorption and (3) increased number of vertical surfaces that absorb short-wave radiation and restrain long-wave radiation (Voogt 2002). As a result, the urban area in particular seasons might show higher air temperatures by $1-3{ }^{\circ} \mathrm{C}$ compared to the surrounding open land (Dobrovolný et al. 2012, Vysoudil 2012). Furthermore, in terms of chronology, it is not a constant value. For example a comparison of stations in Prague demonstrates that from the second half of $20^{\text {th }}$ century the urban heat island intensifies, especially in spring and summer (Žák et al. 2015).

Meteorological stations located in residential areas (Met, Arb, Sob, VDB) do not lie in the city centre or in the line Slatina-centre-Královo Pole identified as the most influenced by urban heat island phenomena (Dobrovolný et al. 2012). For this reason the daily courses of air temperature did not show its gradual systematic augmentation in comparison with the reference station BTp. Only stations Sob and VDB indicated time limited increase of air temperatures around noon in summer months. On the other hand, the station Met manifested slight increase of air temperature in the evening related to the position in proximity of vast concrete parking lot. According to accessible studies (for example Oke 2006) it is stated, that the impact of surroundings on a station is limited to $500 \mathrm{~m}$. This fact leads to a consideration, whether it is correct to regard the selected professional station BTp as referential in relation to those situated in the Brno city area. An abundance of reinforced surfaces in the Brno-Turany airport area is demonstrated in a mode of long-wave radiation mainly in the first half of the night, as witnessed by temperature differences between BTp and stations located in open land (Zab) or mixed urban development site (Rou). The differences increased during radiation type weather.

Results in general indicate, that the essential impact on air temperature measured in selected locations has the spatial positioning (type of surface, nearby objects - sensor shading, anthropogenic heat) and exposition (role of slopes, orientation). Physical-geographical factors (altitude, topography, exposition, vegetation) are most intensely manifested on stations located in open land (Hos, $\mathrm{Zab}$ ). Those types of station can be recommended as background stations for studies of urban heat island and its specifics. Amateur meteorological stations could be sorted in three categories based on present and the preceding study (Dejmal et al. 2018): unusable (totally excluded from this study), partially usable (Mok, Siv, Hol, Laz) and completely usable (Hos, Rou, Sob, Zby). All institutional meteorological stations (Arb, Met, VDB, Zab) turned out to be a quality and 
contributive source of data. Therefore there is no reason to a priori eliminate data from nonprofessional stations in case of studies of spatial variability of air temperature and related topics (UHI). Increasing number of qualitatively satisfactory amateur stations is a promise for the future. However, before incorporating such data into spatial analyses it is necessary to thoroughly check and evaluate them.

\section{Acknowledgement}

This research runs in the collaboration with the project of specific research SV16210/2. We would also like to thank all the individuals/institutions that participate in the project by providing meteorological data.

\section{References}

AMS o. s. 2012. Amatérská meteorologická společnost [online]. AMS o. s., 2012 [cit. 2018-08-29]. Available from: http://www.amsos.cz/index.php?page=main. BRISTOW, R. S. et al. 2005. Emergency Preparedness and Tourism: Both Win with Help of the Amateur Meteorologist. In Peden, Schuster, J. G., Rudy, M. (eds.) Proceedings of the 2005 northeastern recreation research symposium, April 10-12, 2005; Bolton Landing, NY, 2006, General Technical Report, pp. 135-139.

ČHMÚ 2011: Český hydrometeorologický ústav [online]. ČHMÚ, 2011 [cit. 201808-28]. Available from: http://portal.chmi.cz/.

DEJMAL, K. et al. 2018. Possibilities of air temperature data processing from the meteorological stations in Brno and surrounding area. In Useful Geography: Transfer from Research to Practice. Proceedings of 25th Central European Conference. Brno: Masaryk University, 2018. pp. 119-131. ISBN 978-80-2108908-2.

DOBROVOLNÝ, P. 2012. Klima Brna: Viceúrovňová analýza městského klimatu. Brno: Masarykova univerzita, 2012. ISBN 978-80-210-6029-6.

DOBROVOLNÝ, P. 2013. The surface urban heat island in the city of Brno (Czech Republic) derived from land surface temperatures and selected reasons for its spatial variability. In Theoretical and Applied Climatology. vol. 112, no. 1-2, pp. 89-98.

OKE, T. R. 2006. Initial Guidance to Obtain Representative Meteorological Observations at Urban Sites. Instrumental and observing methods, Report No. 81. WMO/TD No. 1250, WMO, 2006 [cit. 2018-09-20]. Available from: http://citeseerx.ist.psu.edu/viewdoc/download;jsessionid=88F0B2082DD85B9 B27FE98127924DEAB?doi=10.1.1.694.2319\&rep=rep1\&type=pdf

RÉPAL, V. 2012. Fyzika atmosféry. Brno: Univerzita obrany, 2012. ISBN 978-807231-857-5. 
TOLASZ, R. 2007. Atlas podnebi Česka. Praha: Český hydrometeorologický ústav, 2007. ISBN 978-80-86690-26-1.

VOOGT, J. A. 2002: Urban heat island. In Encyclopedia of global environmental change. pp. 660-666. ISBN 0-471-97796-9.

VYSOUDIL, M. 2012. Podnebi Olomouce. Olomouc: Univerzita Palackého v Olomouci, 2012.

WORLD METEOROLOGICAL ORGANIZATION. 2008. Guide to meteorological instruments and methods of observation. 7th ed. Geneva: World Meteorological Organization, 2008. 716 p.

ŽÁK, M. et al. 2015. Co víme o tepelném ostrovu Prahy? In Vytápění, Větrání, Instalace. roč. 24 , č. 1, s. 10-15.

RNDr. Karel Dejmal, Ph.D.

Mgr. Petr Kolář, Ph.D.

Ing. Josef Novotný, Ph.D.

Ing. Alena Roubalová

Univerzita obrany

Kounicova 65, 602 00, Brno, Czech Republic

E-mail: alena.roubalova@unob.cz 